\title{
Five models of capitalism
}

\section{LUIZ CARLOS BRESSER-PEREIRA*}

Besides analyzing capitalist societies historically and thinking of them in terms of phases or stages, we may compare different models or varieties of capitalism. In this paper I survey the literature on this subject, and distinguish the classification that has a production or business approach from those that use a mainly political criterion. I identify five forms of capitalism: among the rich countries, the liberal democratic or Anglo-Saxon model, the social or European model, and the endogenous social integration or Japanese model; among developing countries, I distinguish the Asian developmental model from the liberal-dependent model that characterizes most other developing countries, including Brazil.

Keywords: capitalism; models; varieties of capitalism.

JEL Classification: O-01; N-01.

When we consider history in terms of stages, we unavoidably also consider it in terms of convergence. Each model of capitalism has a distinct way of organizing production at company level, gives a distinct role to the state, and has distinct institutions and basic values. But in all modern societies there is a popular demand for democracy - for political freedom and for the right to choose government leaders - and this demand always reflects the power of the bourgeoisie based on capital and the power of the professional class based on organization and knowledge. Democracy has always been a demand of the poor, which became historically possible when the economic surplus ceased to be appropriated by force and was appropriated by the market. The fear on the part of the rich of expropriation by the poor remained, but it waned as the universal suffrage that gradually prevailed in different countries did not lead to the election of revolutionary socialist politicians by the workers. The political system of the most developed countries tended to become democratic, which gave the working class and the middle class

\footnotetext{
* Emeritus professor of Getulio Vargas Foundation. E-mail: bresserpereira@gmail.com. Submitted: 28/April/2011; Approved: 3/June/2011.
} 
enough power to demand from the state social protection and, since the 1980s, environmental protection. Yet capital, the private ownership of the means of production, and the coordination of the economy by the market continued to play key roles in national economic systems, at a time when knowledge and the ability to plan and manage the state and business organizations ensured that the two ruling classes in modern societies were the capitalist class and the professional or technobureaucratic class. Marx, in contrast, taught us long ago that, given the necessary correlation between societies' economic base and their institutional and cultural superstructure, capitalist development tends to lead late-developing societies to converge on the levels of income and on the forms of social organization of the most developed countries. By developing economically, societies tend to combine capital and organization and to be democratic - resulting in what I call technobureaucratic or professional capitalism.

There are, thus, significant forces making for convergence, as long as capital, organization (the collective ownership of organizations by technobureaucrats) and democracy are present in every modern national society. This is confirmed when we think of economic development in terms of stages, as Marx himself did and as sociologists of modernization did between the 1940s and the 1960s - see, for instance, Walt W. Rostow's brilliant The Stages of Economic Growth (1960). There is no point in reopening this debate. Rostow was the subject of widespread criticism from the Left in the 1960s — justified criticism, as would be, in the 1990s, the criticism of Francis Fukuyama (1989) and his theory of the end of history. ${ }^{1}$

Thus, forces making for convergence exist, but they have not yet been able to generate a unique model of capitalism or to support those who believe that backward countries progress through the same stages. Therefore, and because there are better and worse models of capitalism from the standpoint of human development, we should discuss the issue of models of capitalism. Capitalism is, or tends to be, technobureaucratic everywhere, as long as capitalists and professionals, associated but in constant conflict, share power and privilege. But that is not enough to justify the prediction that professional capitalism will be identical everywhere. Different historical and political experiences and the relative backwardness of some nations are sufficient justification for elaborating several models of capitalism - in both developed and developing countries.

In the 1990s, at the height of capitalism's 30 neoliberals years (1979-2008), its intellectuals proclaimed the victory of the Anglo-Saxon model, the model that was the most pure "market society". Or, more accurately, "market economy", since for these intellectuals there is no society but only the market, only agreements to buy or sell enabled by usually low transaction costs. "In the beginning was the market", they said, and it was only because in certain cases transaction costs were high that the "distortion" consisting of the organization (in particular the state) appeared.

\footnotetext{
${ }^{1}$ Among the major left-wing sociologists, C. Wright Mills (1959) and, among the major nationalist ones, Guerreiro Ramos (1958), notably criticized the sociology of modernization.
} 
This is not the place to discuss how ideological and absurd this kind of thought is. But it is worth stressing, as Robert Boyer $(2004$, p. 10) did, a fundamental mistake in the economic theory: "for the most part, economists continue to study the market economy without daring to deal with capitalism as an economic system". That is to say, they ignore the fact that economic systems are social and political systems; they are composed not merely of purchase and sale relationships, but of economic relationships regulated by the state - a state that expresses the will of the system of forces existing in society. There are no economic relationships without political relationships, there is no economic analysis without political analysis. Capitalism is not a mere abstraction - a market economy — but rather a historically situated economic system, always evolving, always reflecting technological change and the political struggles through which ideologies and institutions are expressed and modified. Neoliberal theory, naively deterministic and pathetically ideological, according to which the Anglo-Saxon model would be "a golden straightjacket", presumes a single economic ideal toward which other models tend to evolve, as "market forces become victorious". Even if there is a convergence, it is far from being linear (it is always subject to crises and regressions), and far from being deterministic (rather, it is increasingly subject to the free will of humans expressed in politics). Just as it made no sense to say that history was inevitably moving toward socialism and communism, it makes no sense to think that history is moving towards some paradise identical with American capitalism - a version of capitalism that is currently more backward than European capitalism, since it is further from the goals of security, freedom, economic welfare, social justice and environmental protection than the most developed European countries. Still, according to Boyer, "the hypothesis of a canonical model around which a number of smaller elements would revolve was disproven in favor of a vision which insists on the strong dependence of the present situation on past political engagements". Evidently, technology is important in bringing together the advanced forms of capitalism; institutions also have this role, but, adds Boyer, "the linearity of the impact of institutions on performance indicators is also debatable". There are, therefore, tendencies towards convergence, but we cannot talk of a canonical model of capitalism or of necessary linearity and convergence in the process of economic development. We must think about models of capitalism.

Since the 1990s an extensive literature has emerged on models of development. To me, the "founding" classification is that of Gøsta Esping-Andersen (1990) who distinguished three models of the social state or the welfare state: "liberal" (United States), "corporate" (Germany) and "social democratic" (Scandinavian countries). Michel Albert (1991) compared the "American" and the "Rhenish" (French and German) models. Peter Hall and David Soskice (2001) developed a theory of "varieties of capitalism" using as the main criterion the relationships existing inside business enterprises; they divided OECD countries into "liberal market economies" and "coordinated market economies". Elaborated as it is in an academically rigorous way, it is today the prevailing theory on the subject. John D. Stephens (2002) made an interesting distinction between "liberal democratic states" (such as the 
United States), "Christian democratic welfare states" (such as Germany), "social democratic welfare states" (the Scandinavian states), and "wage-earner welfare states" (Australia and New Zealand). Boyer's theory (2004), for its part, based on modes of regulation, distinguished four types of advanced capitalism: "market" (such as the United States), "meso-corporatist" (such as Japan), "public/integration" (France) and "social democratic" (the Scandinavian countries). Ben Ross Schneider $(2008,2009)$, in the line of the varieties of capitalism approach, adopts as basic criterion the "mechanisms of allocation" (markets, negotiation, networks, and hierarchy) and accordingly sees four varieties of capitalism: liberal market economies, coordinated market economies, network market economies (Japan), and hierarchical market economies (middle income countries as Turkey, South Africa, and the Latin American, and the South East Asia, countries). This last classification is a substantial improvement in relation to the original Soskice and Hall one in so far as among developed countries it distinguishes the European from the Japanese countries, and that it includes middle income countries in the models of capitalism in so far as "middle income regions like Latin America may still lag as far behind developed countries in terms of GDP per capita as they did decades ago, but on many social and economic indicators contemporary middle income countries are as 'modern' as developed countries" (Schneider, 2008, p. 4).

\section{FIVE MODELS OF CAPITALISM}

Although these classifications differ because they use different criteria, they eventually present significant similarities. The classification I have been defending for some time is also similar, but, like Esping-Andersen's classification and unlike those of Hall and Soskice, and Boyer, and Schneider which emphasize differences at the production level and therefore between business enterprises, I use a political criterion to distinguish the models of capitalism in rich countries, namely, the historical decisions they made on the nature and degree of state intervention. Besides, I classify developing countries that have already undergone their capitalist revolutions into two models of "developing" capitalism: the developmental model and the liberal-dependent model. By adopting the state as the key criterion for the classification of the models of capitalism, I am, in the first place, stressing the fundamental significance of institutions. After all, the state embodies the constitutional and legal system and the organization that guarantees it. It is, therefore, the major institution in capitalist societies. By asserting that the nature of this state is a "decision" of the society, I am stressing the political nature of the criterion I adopt. The state, even a non-democratic one, is always a political construction. As long as democracy improves its quality, or as long as there is democratization, the deliberate aspect of this construction becomes stronger. The political decision of the citizens in democratic societies on the size of the state, on how large social expenditures should be, determines whether the state and its associated capitalism will be social (a welfare state) or merely liberal. In addition, the degree of regulation the 
state should exercise over social and economic life determines the definition of the model of capitalism. Therefore, I do not use as classification criteria the internal structure of business enterprises or the types of capital-labor relationship that exist in them, as does Hall and Soskice's theory of the varieties of capitalism. I do not recognize significant structural differences among business enterprises; and differences in the capital-labor relationship, which are indeed significant, are regulated by the state.

Using as primary criteria the size of the state and the degree of regulation aimed at promoting economic development and at protecting work and reducing economic inequality, I identify three models of capitalist society in modern developed countries: the "liberal democratic model" that characterizes Anglo-Saxon countries, the "social model" or "welfare model" that characterizes the most developed European countries, and the "endogenous social integration model" or "Japanese model" of which Japan is the canonical representative. But it no longer makes sense to limit ourselves to the rich countries. Among developing countries, there are, as well as poor countries, middle-income countries that have already completed their capitalist revolutions and must be considered. Among these fully capitalist countries, I draw a distinction between the "developmental model" that characterizes China, India and other dynamic Asian countries that are growing very fast, and the "liberal-dependent model" that characterizes the other middle-income countries such as Argentina, Brazil, Turkey, Mexico and South Africa, whose average GDP growth rates tend to be substantially lower. Yet, in the 2000s, the failure of the dependent-liberal model in promoting growth, financial stability, and reduction of inequality led countries like the first three countries to move towards the developmental model of capitalism.

It is evidently possible to make a classification of capitalism in many other ways. Among European countries, for instance, I make no distinction between the "social democratic model" and the "corporatist model", as Esping-Andersen did, since although I recognize differences between the two I do not consider these differences to be sufficiently great. Thus, a large social state exists not only in Scandinavia; it is present also in several other developed European countries. On the other hand, models that are essentially the same may be given different names: Boyer, for instance, calls the Asian model "meso-corporatist" whereas I prefer to call it the "Japanese model" or the model "of endogenous social integration", since corporatism exists also in European countries; and what I define as endogenous social integration - the construction of a system of solidarity within households and within business enterprises, without the state's direction — is exclusive to Japan and other Asiatic countries.

In the liberal democratic model, state intervention is as limited as possible. And it is always minimized in terms of discourse - the neoliberal discourse. The state has a limited role in education, in health care and social care, and in social protection or welfare. "Labor" protection - that is, labor protection laws whose cost falls on business enterprises and not on the state - is minimal. The number of government-owned companies is minimal. The regulation of business enterprises 
is limited. Individualism, technological innovation and competition prevail over cooperation and social solidarity.

In the social democratic model, the power of the professional class, especially the public bureaucracy, is greater than it is in the Anglo-Saxon model. State intervention takes place at the production or industrial-policy level, in labor protection, and in the free or almost free provision of collectively used social services. Although, among the European countries in this group, some are more social than others because they guarantee social rights more extensively and effectively, I prefer, on the aggregate level with which I am dealing, not to differentiate Rhineland capitalism from the Scandinavian variety: they are both social democratic; and they seek to integrate and to build solidarity through state regulation. This model moved toward the Anglo-Saxon model in the neoliberal years, but it remains very different. After the 2008 global financial crisis, any movement is in another direction, since this crisis was basically a crisis of neoliberalism.

Yet in the Japanese model of capitalism the state leaves social protection to households and business enterprises, and therefore to the traditions or to the spirit of solidarity they share. This model of capitalism is characterized by a greater economic equality than exists in Europe, but it does not rely on the institutions of the social state: individual security is left to households and business enterprises. This model also moved in several aspects toward the liberal model. For example, lifetime job security in business enterprises, which is perhaps the most specific characteristic of this model, is disappearing. But the type of capitalism that exists in Japan continues to be very different both from the liberal model and from the social or European model. I will not discuss this model here because it is very distant from those in the West. In Japan, the public bureaucracy and large private bureaucracies within the big corporations play a key role. This model faced a crisis in 1990, since when it has been unable to restore economic growth.

Among the developing countries, the developmental model is characterized by the informal existence of a national development strategy - a system of laws, public policies, agreements and understandings that create lucrative investment opportunities for entrepreneurs - implemented by strong state intervention in the economy so as to make this strategy operational, and by a low level of labor protection. This model is obviously inspired by the Japanese model.

Finally, the liberal-dependent model is characterized by the dependent nature of its elites in varying degrees, and by the absence of a national development strategy. From the standpoint of the social structure, this model is characterized by a political alliance between an incipient industrial bourgeoisie and an equally incipient public and private bureaucracy. In the first stage, the state, apart from being a promoter of economic development, is a producer, because it is responsible for forced savings and for investments that require vast amounts of capital and are slow to provide a return. At this stage, the professional or technobureaucratic nature of capitalism is very clear. In the second stage, after a powerful entrepreneurial system is established, the state reduces its investments, but continues to play a significant role as a promoter. And, in a few cases, such as the Brazilian one, it is 
characterized by a high degree of inequality, and develops, as a trade-off, an extensive social protection system. Yet the dynamic Asian countries that do not display such inequality keep the state away from the social area. Some countries, such as Brazil, pursued a developmentalist strategy between 1950 and 1980 and achieved impressive growth; but, after going through a huge crisis in the 1980s, they submitted to the reforms and macroeconomic policies that originated in Washington and New York. The list of countries that conform to the liberal-dependent model of capitalism is naturally changeable. Since the early 2000s Brazil and Argentina have been making efforts to regain national autonomy and to define a national development strategy.

Why does capitalism display a range of models? The differentiation between the three models of rich countries and the two models of middle-income countries reflects, on the one hand, the backward nature of the middle-income countries and the imperialist relationship between them and rich countries; on the other hand, it reflects the advantage that middle-income countries have over rich ones in global competition because of their cheap labor and the possibility of absorbing technology already developed by the rich countries. As for the differences between the three models of capitalism in the rich countries, these result from the key role the state plays in the coordination of modern societies. The state defines the model of capitalism. Evidently, this occurs in a dialectic way, because no constitutional or legal system survives unless it enjoys social legitimacy. But why do we have the social state in the European model and the liberal state in the Anglo-Saxon model? Probably because socialist or social democratic parties in the European model had and still have a greater influence in the building of their corresponding states than in the Anglo-Saxon model countries: in other words, because the political center of the European model countries is further left than the political center of the AngloSaxon model countries. In the United States, whether because capitalism was hugely successful since the beginning of its history or because socialism there was violently repressed, so far no party there may be considered as social democratic.

\section{THE JUSTICE ISSUE}

According to Esping-Andersen (1990, p. 20), the liberal state that characterizes the United States performs a "residual" function: the state takes responsibility when the individual or the family fails. ${ }^{2}$ This kind of state and model of capitalism, unlike the European and the Japanese models, limits universal rights and adopts a policy of individualized social care based on people's income. Consequently, its effect in terms of reducing economic inequality remains limited. Esping-Andersen also discusses corporatism. The concept of corporatist capitalism was originally

\footnotetext{
${ }^{2}$ Esping-Andersen (1990, p. 20) bases this claim on the classic distinction made by Richard Titmuss (1958) between the "residual" and the "institutional" welfare state.
} 
proposed by Philip Schmitter, whose paper "Still a century of corporatism?" (1974) may be considered to have originated research on models of capitalism. Schmitter focused his attention on Germany, and showed how different German capitalism is from American capitalism, essentially because economic coordination is not simply based on lightly (and, so, poorly) regulated markets, as happens in liberal capitalism, but on a more powerful state and mostly on a semi-formal agreement between workers and capitalists, mediated by the state. The workers have an interest in the successful management of companies, and capital-labor disputes are mediated by the state on the basis of an understanding between business enterprises and workers, in other words on the basis of a coalition of classes in which workers are guaranteed both a stake in productivity gains and state provision of social and scientific and high education services in social security, education and, in particular, health care.

The European or social model of capitalism is deeply entrenched in European society, and so its emergence did not require a social democratic party to be in power. The social state in Germany, for instance, was for the most part achieved by the conservative party, that is, the Christian Democratic Party, which called its policy the "social market economy". The center-left parties are always more favorably inclined toward the social state, but the social nature of European capitalism derives particularly from the vision that each national civil society has of the state's role and from the degree of solidarity between its members. It is certainly because left-wing parties had a significant influence on the construction of the society and the state of the most developed European countries (which did not happen in the United States) that European capitalism is different from liberal capitalism. In the 1980s and 1990s, the neoliberal ideological wave militated against those improvements and promoted a move back from the social state to the liberal democratic state; but it did not succeed. It was more successful in implementing radical reforms, such as the privatization of the basic social security system in some developing countries that were incapable of protecting themselves against ideological excesses. ${ }^{3}$

Opposition between conservative and liberal political parties characterized classic capitalism; opposition between liberal political parties (now, conservative parties) and social democratic ones defines professional capitalism. All the models of capitalism discussed here are models of professional capitalism. It is true that in the European model and in the Japanese model the professionals have achieved more power than in the liberal model of capitalism. But the professional class is present and powerful in all of them. In every country a conservative or a centerright party and a progressive or social democratic party alternate in power. But the victory of a conservative or liberal party does not mean that capitalism will revert to classic capitalism; capitalism remains technobureaucratic and social democratic. This victory means only that the liberal forces that oppose the social state or social

\footnotetext{
${ }^{3}$ This is the case with Chile and Argentina regarding the reform of social security.
} 
democratic capitalism have moved forward slightly, just as the victory of the progressive or social democratic party means the opposite.

In the United States, the New Deal in the 1930s was a step toward social democratic capitalism, but the process of change was not completed. Conservative forces continued to be powerful, and have so far prevented American society from progressing from liberal to social capitalism. Europe's social state was under attack during the 30 neoliberal years, but it resisted: labor laws have been softened, but there was no decrease in public social expenditure; rather, it increased. Nowadays, after the 2008 global financial crisis signaled the collapse of neoliberalism, I find it hard to believe that American conservatives will be able to prevent their society's transition to the social or welfare model of capitalism.

Given the ideological hegemony exercised by the United States in the 1990s, it was suggested that the liberal model of capitalism would be superior to the social model. But when we compare them in terms of the five political goals of modern societies - security, freedom, welfare, social justice, and environmental protection - it is hard not to see the better results achieved by the more solidary model existing in Europe. In Europe, left-wing and right-wing governments alternate in power, as the Democratic and the Republican parties do in the United States, but the concepts of right and left make sense only in relation to a political "center". Well, this center in Europe, even in Britain, is clearly more to the left than the center in the United States. Whereas individualism prevails in the liberal model of the United States, in the social or welfare model of the Europe of the euro, even at the height of neoliberalism, solidarity and social cooperation played a major role. Among many symptoms of what I am saying is the society's willingness to pay taxes. Whereas in the United States the tax burden is a little over 30\% of GDP, in Europe it approaches $50 \%$. Since these countries are democracies, these tax burdens result from the citizens' political decisions. When, in Europe, citizens accept or decide to pay more taxes than in the United States, this means that they opt for relatively more egalitarian collective consumption and for relatively less individual consumption. This collective consumption is achieved through the provision of education, health care, and social security services free of charge or almost free of charge, financed by the state. When we compare European capitalism with the American version, we observe that, in the social model of capitalism, income distribution is more equal and social rights are more widely and more generously guaranteed. Countries such as Britain, New Zealand and Australia are in an intermediate position. Despite United States' immense wealth, only in 2010 was a law approved considerably extending health care, but without making it universal as in Europe. If the quality of a model of capitalism and of a type of state is measured by how much can it provide of the five public goods valued by modern societies (security, freedom, social justice, welfare and environmental protection), there is little doubt that the most developed European societies have progressed more in each of those goals than the United States. Robert Goodin et al. have used Esping-Andersen's classification of the models of capitalism as "liberal", "corporatist" and "social democratic" to conduct an investigation in three countries that represent the three 
types of welfare state: the United States, Germany and the Netherlands. After an extensive analysis, they concluded that the social democratic model of promoting welfare is better than the other two:

The social democratic welfare regime is at least as good as (and usually better than) either of the other welfare regimes in respect of all the social objectives that we traditionally set for our welfare regimes. $(1999$, p. 262)

\section{THE EFFICIENCY ISSUE}

Would the European model of capitalism be not only more fair but also more efficient, that is, more able to promote economic development? Neoliberal ideology categorically states that it is not; it also maintains that the liberal model tends to encourage hard work and that markets allocate the factors of production efficiently. But since the 1980s productivity growth rates in Europe's most advanced countries have been comparable to those of the United States and of Britain. Why? Probably because, as it is possible to observe, efficiency does not result from market competition alone but from the combination of competition and cooperation, of individualism and solidarity, of the free market and its management. The market is always the chief instrument of economic coordination - which is why capitalism prevailed - but markets are always social constructs and are regulated by the state; and there is no reason to believe that they will be more efficient if left entirely "free", unless we believe the myth that real markets approach the model of perfect competition. It is true that in some European countries excessive regulation of businesses and labor may reduce competition and represent a negative incentive to entrepreneurship. But, as a trade-off, in the most egalitarian and protected societies in Europe social cohesion is greater and so is the legitimacy of the state, its laws and governments. In addition, the greatest social homogeneity reflects cooperation and encourages efficiency. More extensive and generous social security in terms of unemployment benefits makes workers more willing to accept a decrease in their job security (which is important for the competitiveness of enterprises). Greater flexibility in labor markets implies an increase in job insecurity and in part-time employment; the trade unions, in turn, have agreed to limit their wage demands in order to ensure companies' international competitiveness. However, the losses for the workers from this flexibility have been partially offset by the flexicurity system initially developed in Denmark: while trade unions agreed to limit their wage demands and to forgo some job security, the government extended the duration of unemployment benefits and developed effective policies to retrain the unemployed and help them find new jobs. Therefore, the Danes did not need to imitate the American system and dismantle the social state, as neoliberals had presumed. At the beginning of the twenty-first century, the average unemployment rate in European countries was roughly identical to that in the United States, and, although 
gross economic growth was lower in Europe, it was practically the same in per capita terms since population growth was much faster in the United States. And the European countries kept their social state. Expenditure on collective consumption services (identical for everyone), financed by taxes, continued to amount to around $30 \%$ of GDP in western and northern Europe, whereas in the United States it corresponded to less than $15 \%$ of GDP, indicating a lower level of social solidarity.

During the 30 years up to 2008 , the neoliberals and neoconservatives who dominated the American state (whose model of capitalism was already close to their ideal) tried to extend their model to the rest of the world. But, in spite of all its economic power, all its military power, and all its soft power expressed in its prestigious brands, in its remarkable universities, in its popular music and in its movie industry, the ability of the United States to export its own type of capitalism proved to be limited. It proved to be limited in Europe because, if it is true that European countries "softened" their labor protection laws, they were nevertheless able to retain and even expand their social state. It proved to be limited in Japan for cultural reasons and because neoliberalism coexisted in Japan with the long nearstagnation that emerged in 1990, after the Japanese yielded to American pressure and appreciated their currency. It proved to be limited in the dynamic Asian countries, including China and India, because these countries understood that the neoliberal reforms prescribed by the Washington Consensus conflicted with their national development strategies based on fiscal austerity, competitive exchange rates, and a strategic role for the state. But it proved to be successful in other developing countries that, by implementing neoliberal reforms, by opening their financial markets, and by practicing the macroeconomic policy recommended by Washington, based on an appreciated exchange rate "to fight inflation", were faced with financial crises and with economic growth rates substantially below their potential. But, since the early 2000s, the election of left-wing and nationalist political leaders in Latin American countries has reflected the failure of neoliberal reforms and the attempt of these countries to adopt a new developmentalism inspired by the Asian developmental model. ${ }^{4}$

\section{REFERENCES}

ALBERT, Michel (1991) Capitalisme Contre Capitalisme. Paris: Éditions du Seuil. BOYER, Robert (2004) Une Théorie du Capitalisme. Est-elle Possible? Paris: Odile Jacob.

\footnotetext{
${ }^{4}$ In the economic development domain, since 1991 I have developed a whole set of economic models and economic and political analyses that have led me to define a national development strategy, based on the Asian developmental model, which I called "new developmentalism". Its theoretical basis is a structuralist development macroeconomics. These ideas are developed in Globalization and Competition (Bresser-Pereira, 2010).
} 
BRESSER-PEREIRA, Luiz Carlos (2010) Globalization and Competition. New York: Cambridge University Press.

ESPING-ANDERSEN, Gøsta (1990) The Three Worlds of Welfare Capitalism. Princeton, NJ: Princeton University Press.

FUKUYAMA, Francis (1989) “The end of history?”. The National Interest, 56 (Summer).

GOODIN, Robert E. et al. (1999) The Real Worlds of Welfare Capitalism. Cambridge: Cambridge University Press.

GUERREIRO RAMOS, Alberto (1958) A Redução Sociológica. Rio de Janeiro: Instituto Superior de Estudos Brasileiros (ISEB).

HALL, Peter A. and David SOSKICE (2001) “An introduction to Varieties of Capitalism”, in Hall and Soskice (2001): 1-70.

HALL, Peter A. and David SOSKICE (eds.): (2001) Varieties of Capitalism. Oxford: Oxford University Press.

HUBER, Evelyne (ed.) (2002) Models of Capitalism: Lessons for Latin America. Pennsylvania: Penn State University Press.

MILLS, C. Wright (1959) The Sociological Imagination. Oxford: Oxford University Press.

ROSTOW, Walt W. (1960) The Stages of Economic Growth. Cambridge: Cambridge University Press.

SCHMITTER, Philippe C. (1974) “Still a century of corporatism?”. Review of Politics 36(1): 7-52.

SCHNEIDER, Ben Ross (2008) "Comparing Capitalisms: Liberal, Coordinated, Network, and Hierarchical Varieties”. Copy: Northwestern University, March 2008, 37 pgs.

SCHNEIDER, Ben Ross (2009) "Hierarchical market economies and Varieties of Capitalism in Latin America". Journal of Latin American Studies 41: 553-575

STEPHENS, John D. (2002) "European welfare state regimes: configurations, outcomes, transformations", in Evelyne Huber (2002): 303-338.

TITMUSS, Richard (1958) Essays on the Welfare State. London: Allen and Unwin. 